RA233 is a new derivative of pyrimido-pyrimidine and its effects on platelet behaviour in vitro are reported and a comparison is made with its analogue RA433. RA233 inhibited calcium-induced platelet aggregation in the Chandler tube and also in the modified turbidimetric system; it decreased platelet aggregation as assessed by the optical density fall in the turbidimetric system and reduced the total duration of platelet aggregation. Despite these changes in platelet activity the clotting-time was uninfluenced in this system. In the Chandler tube system, both RA233 and RA433 significantly prolonged the platelet aggregation time, whereas in the assessment of calcium-induced platelet aggregation using the turbidimetric system, RA233 significantly prolonged platelet aggregation time whereas RA433 did not; both RA233 and RA433 reduced significantly the optical density fall and reduced the duration of aggregation, which are presumptive measures of the degree of aggregation of platelets. RA233 proved to be a more potent inhibitor than RA433 of A.D.P.induced platelet aggregation and of platelet retention by glass beads. Neither drug affected platelet disaggregation. RA233 and RA433 decreased the release of platelet factor 3 induced by kaolin, but there was no significant difference in their activity.

RA233 and RA433 were effective in inhibiting clot retraction of whole blood and of platelet-rich plasma. The addition of A.D.P. before recalcification partially corrected the inhibition in clot retraction induced by RA233, but not that by RA433. This observation suggests that RA233 may have a combined effect on thrombasthenin, the contractile protein of platelets, and possibly on the generation of energy required for clot retraction. The concentrations of RA233 and RA433 used in the experiments on clot retraction are, however, unlikely to be attained in man in vivo.

The results show that RA233 has properties similar to dipyridamole and RA433 in altering platelet behaviour in vitro, but is significantly more potent when tested in some in-vitro models. RA233 is well absorbed by mouth and relatively non-toxic when administered to experimental animals (R. Kadatz, personal communication, 1969).
The hypothesis, however, of a therapeutic gain from reducing platelet stickiness in occlusive vascular disease remains to be proved, and once toxicity studies have been completed it would be of major importance to mount largescale clinical trials with the pyrimido-pyrimidine group of compounds.

Thanks are due to Professor E. M. McGirr for his interest in this work. We are grateful to the Medical Research Council and to Dr. J. H. Shelley of Messrs. Boehringer Ingelheim for financial assistance.

\section{REFERENCES}

Born, G. V. R. (1962). fournal of Physiology, 162, 67P.

Born, G. V. R., Honour, A. J., and Mitchell, J. R. A. (1964). Nature, 202, 761 .

Chandler, A. B. (1958). Laboratory Investigation, 7, 110.

Cunningham, G. M., McNicol, G. P., and Douglas, A. S. (1965). Lancet, 1, 729 .

Dacie, J. V. (1956). Practical Haematology, 2nd ed. London, Churchill.

Elkeles, R. S., Hampton, J. R., Honour, A. J., Mitchell, J. R. A., and Prichard, J. S. (1968). Lancet, 2, 751 .

Emmons, P. R., Harrison, M. J. G., Honour, A. J., and Mitchell, J. R. A. (1965a). Nature, 208, 255. Emmons, P. R., Harrison, M. J. G., Honour, A. J., and Mitchell,
J. R. A. (1965b). Lancet, 2, 603

Forbes, C. D., McNicol, G.'P., and Douglas, A. S. (1969). British Medical fournal, 2, 483.

Gray, G. R., Wilson, P. A., and Douglas, A. S. (1968). Scottish Medical fournal, 13, 409.

Hassanein, A. A. (1969). Ph.D. Thesis, University of Glasgow.

Hellem, A. J. (1960). Scandinavian fournal of Clinical and Laboratory Investigation, 12, Suppl. No. 51.

Hirsh, J., McBride, J. A., and Dacie, J. V. (1966). Australasian Annals of Medicine, 15, 122.

Honour, A. J., and Mitchell, J. R. A. (1963). Nature, 197, 1019.

Jfrgensen, L, and Borchgrevink, C. F. (1964). Acta Pathologica et Microbiologica Scandinavica, 60, 55 .

Mustard, J. F., Murphy, E. A., Rowseli, H. C., and Downie, H. G. (1962). American fournal of Medicine, 33, 621 .

Mustard, J. F., Rowsell, H. C., and Murphy, E. A. (1964). American fournal of the Medical Sciences, 248, 469 .

Spaet, T. H., and Cintron, J. (1965). British fournal of Haematology, 11, 269.

Sullivan, J. M., Harken, D. E., and Gorlin, R. (1968). New England Fournal of Medicine, 279, 576.

\title{
Clofibrate, Serum Enzymes, and Muscle Pain
}

\author{
A. F. SMITH, ${ }^{*}$ M.B., M.R.C.P.ED., M.R.C.PATH.; W. G. MACFIE, $†$ M.B., M.R.C.P.ED.
}

M. F. OLIVER, $\ddagger$ M.D., F.R.C.P., F.R.C.P.ED.

British Medical fournal, 1970, 2, 86-88

Cummary: Serum creatine kinas (C.K.), aspartate aminotransferase (G.O.T.), and alkaline phosphatase (A.P.) activities were measured in 211 men with serum cholesterol concentrations in the upper one-third of the normal distribution. Of these, 110 were receiving clofibrate and 101 were given identical capsules containing olive oil. These investigations were also carried out on 85 healthy men with low serum cholesterol levels not receiving clofibrate.

No differences were observed in C.K. and G.O.T. activities between any of these groups; A.P. was significantly lower in the clofibrate-treated group. No significant alterations in C.K. occurred during serial observations made in 15 patients with ischaemic heart disease over a period of five months. No instance of myalgia or muscle stiffness

\footnotetext{
* Lecturer in Clinical Chemistry.

+ Assistant Director, Heart Disease Prevention Triai. $\$$ Physician and Senior Lecturer in Medicine, Departments of Cardiology

The Royal Infirmary, Edinburgh EH3 9YW.
}

\section{was recorded in $\mathbf{4 5 2}$ men who had received clofibrate for} one year.

It is concluded that raised C.K. and G.O.T. concentrations and the occurrence of myalgia are uncommon accompaniments of clofibrate treatment.

\section{Introduction}

Raised serum creatine kinase (C.K.) activities have been observed in 5 out of 60 patients with hyperlipoproteinaemia during treatment with clofibrate (Atromid-S), and severe myalgia and muscle stiffness developed in two patients (Langer and Levy, 1968). Because of these complications it has been suggested that frequent determinations of C.K. should be made on all patients receiving this drug (Lancet, 1968). Transient rise of serum aspartate aminotransferase (G.O.T.) and permanent depression of alkaline phosphatase (A.P.) have been reported to occur during clofibrate administration (Oliver, 1962; Hellman et al., 1963).

The purpose of this paper is to report a study in which the serum levels of these enzymes (C.K., G.O.T., and A.P.) were 
measured in normal men after six months' administration of clofibrate and in a comparable control population; in addition serial observations were made in a small group of patients with ischaemic heart disease.

\section{Normal Men}

\section{Subjects Studied}

A primary prevention trial to determine whether reduction of raised serum lipids will lead to less ischaemic heart disease in normal men aged 30-59 years has been conducted in Edinburgh for the past four years (Oliver, 1968); clofibrate is being used to lower serum lipids. The trial includes the following groups: (1) men with serum cholesterol levels in the highest third of the cholesterol distribution-these are being treated with $1.6 \mathrm{~g}$. clofibrate daily; (2) men with serum cholesterol levels in the highest third of the cholesterol distribution-these are being given small quantities of olive oil; and (3) men with serum cholesterol levels in the lowest third of the cholesterol distribution-these are being given olive oil.

The men included in this study are drawn from the normal blood donor population. Those with high serum cholesterol levels are randomly allocated to treatment or control groups (groups 1 and 2), and alternate men with low serum cholesterol levels are selected for group 3.

Clofibrate and olive oil are prepared in identical capsules. The design is such that "blindness" exists concerning serum cholesterol levels as well as treatment, and none of us or the technicians involved in this report had access to the code until the study was completed.

At present 4,000 men are participating in this trial. The basis for this report is a sample of men attending at their routine six-monthly clinical check, when a blood sample is customarily taken. Serum is separated, stored overnight at $+4^{\circ} \mathrm{C}$., and analysed next morning.

\section{Ischaemic Heart Disease Patients}

A small group of 15 patients ( 9 males and 6 females) with a history of angina or of previous myocardial infarction were followed serially for five months after we started treatment with clofibrate. Measurements were made twice before treatment and at one, three, and five months during treatment.

\section{Methods}

Serum Creatine Kinase.-A modification (Smith, 1967) of a kinetic spectrophotometric method (Rosalki, 1967) with a commercially available reagent kit (CPK Stat Pack, Calbio- chem, Los Angeles 54, U.S.A.) was used. Rate measurements were made at $30^{\circ} \mathrm{C}$. in a Unicam SP 800 automatic recording spectrophotometer. The upper limit of normal for patients at rest is usually regarded as $60 \mathrm{i} . \mathrm{u}_{\mathrm{b}} / \mathrm{l}$., but our experience of ambulant individuals suggests that this is too low and that 100 i.u./1. is a more accurate evaluation. The coefficient of variation for the method was $\pm 6.8 \%$.

Serum Aspartate Aminotransferase.-An AutoAnalyzer modification of the method of Reitman and Frankel (1957) was used. The upper limit of normal for this method is 40 R.F. units $/ \mathrm{ml}$., the standard deviation at this level of activity being \pm 3.5 R.F. units $/ \mathrm{ml}$.

Serum Alkaline Phosphatase.-An AutoAnalyzer method with p-nitrophenyl phosphate as substrate (Morgenstern et al., 1965) was used. Standards were calibrated by a manual method (Kind and King, 1954), results being expressed in King-Armstrong units; the upper limit of normal for this method is $13 \mathrm{~K} . A$. units $/ 100 \mathrm{ml}$., the one standard deviation for the method at this level of activity being $\pm 1.0 \mathrm{~K}$.A. unit $/ 100 \mathrm{ml}$.

Serum Cholesterol.-Technicon AutoAnalyzer method N 24A was used.

Serum Triglycerides.-Determination of glyceride-glycerol was done by the method of Carlson (1963).

\section{Results}

Normal Men.-Creatine kinase activities did not differ significantly between the groups (Table I). In each group several results were considerably in excess of the other findings. Two patients in group 2 had C.K. activities of 320 and 360 i.u./l. There was no apparent reason for these levels; in particular, no recent history of strenuous exercise was obtained. The overall C.K. results showed a log-normal distribution (see Chart) and each of the three groups had an identical distribution. No significant difference in G.O.T. activities was found (Table I). Alkaline phosphatase activities were significantly lower in the clofibrate-treated group $(P<0.001)$. Both control groups showed a number of moderately raised A.P. values-that is, between 13 and $20 \mathrm{~K}$.A. units $/ 100 \mathrm{ml}$. Mean levels and standard deviations for age, height, weight, triceps skinfold thickness, and subscapular skinfold thickness in each of the groups are shown in Table II. In addition, discriminant function analyses were made to relate each of these variables with C.K., G.O.T., and A.P., and no significant correlations were shown.

TABLE I.-Serum Enzyme Levels in Healthy Male Blood Donors after Six Months' Participation in Trial (see Text)

\begin{tabular}{|c|c|c|c|c|c|c|c|c|c|c|c|c|}
\hline \multirow{2}{*}{\multicolumn{3}{|c|}{ Group }} & \multirow[t]{2}{*}{$\begin{array}{l}\text { No. of } \\
\text { Patients }\end{array}$} & \multicolumn{3}{|c|}{$\begin{array}{c}\text { Serum Creatine } \\
\begin{array}{c}\text { Kinase } \\
\text { (i.u./1.) }\end{array} \\
\end{array}$} & \multicolumn{3}{|c|}{$\begin{array}{c}\text { Serum Alkaline } \\
\text { Phosphatase } \\
\text { (K.A. units } / 100 \mathrm{ml} \text {.) }\end{array}$} & \multicolumn{3}{|c|}{$\begin{array}{c}\text { Serum Aspartate } \\
\text { Aminotransferase } \\
\text { (R.F. units/ml.) }\end{array}$} \\
\hline & & & & Mean & S.D. & Range & Mean & S.D. & Range & Mean & S.D. & Range \\
\hline 1. Clofibrate-treated high cholestero & oup & . & 101 & $57 \cdot 2$ & $32 \cdot 5$ & $8-196$ & $7 \cdot 0$ & $2 \cdot 3$ & $3-15$ & $27 \cdot 4$ & $10 \cdot 4$ & $11-86$ \\
\hline 2. Control high cholesterol group & . & . & 110 & $\begin{array}{l}58 \cdot 9 * \\
(53 \cdot 8)\end{array}$ & $\begin{array}{l}47 \cdot 7 * \\
(29 \cdot 0)\end{array}$ & $\begin{array}{r}18-360 \\
(18-176)\end{array}$ & $9 \cdot 8$ & $2 \cdot 7$ & $3-20$ & $26 \cdot 8$ & $11 \cdot 2$ & $16-70$ \\
\hline 3. Control low cholesterol group . & . & . & 85 & $49 \cdot 7$ & $27 \cdot 8$ & $4-164$ & $9 \cdot 5$ & $2 \cdot 9$ & $3-20$ & $24 \cdot 8$ & $13 \cdot 6$ & $13-55$ \\
\hline
\end{tabular}

*This group includes two results of 320 i.u./1. and 360 i.u./1. The figures in parentheses are those obtained if these two results are ignored.

TABLE II.-Serum Cholesterol, Age, Height, Weight, and Skinfold Thickness of the Groups Included in the Study (see Text)

\begin{tabular}{|c|c|c|c|c|c|c|c|c|c|c|c|c|}
\hline \multirow{3}{*}{ Group } & \multirow{3}{*}{$\begin{array}{l}\text { No. of } \\
\text { Patients }\end{array}$} & \multirow{3}{*}{$\begin{array}{c}\text { Cholesterol } \\
\text { Mean } \\
\text { (mg./100 ml.) }\end{array}$} & \multirow{2}{*}{\multicolumn{2}{|c|}{ Age }} & \multirow{2}{*}{\multicolumn{2}{|c|}{ Height (cm.) }} & \multirow{2}{*}{\multicolumn{2}{|c|}{ Weight (kg.) }} & \multicolumn{4}{|c|}{ Skinfold Thickness (mm.) } \\
\hline & & & & & & & & & \multicolumn{2}{|c|}{ Triceps } & \multicolumn{2}{|c|}{ Subscapular } \\
\hline & & & Mean & S.D. & Mean & S.D. & Mean & S.D. & Mean & S.D. & Mean & S.D. \\
\hline 1 & 101 & 258 & $43 \cdot 6$ & 6.7 & $174 \cdot 5$ & $11 \cdot 4$ & $77 \cdot 7$ & $8 \cdot 7$ & $12 \cdot 2$ & $3 \cdot 8$ & $16 \cdot 0$ & $5 \cdot 6$ \\
\hline 2 & 110 & 260 & $44 \cdot 6$ & $7 \cdot 6$ & $174 \cdot 4$ & $7 \cdot 2$ & $77 \cdot 1$ & $9 \cdot 6$ & $12 \cdot 1$ & 3.5 & $16 \cdot 6$ & $5 \cdot 8$ \\
\hline 3 & 85 & 182 & $43 \cdot 5$ & $7 \cdot 3$ & $174 \cdot 8$ & $7 \cdot 1$ & $73 \cdot 5$ & $10 \cdot 2$ & $10 \cdot 4$ & 3.5 & $14 \cdot 5$ & $5 \cdot 8$ \\
\hline
\end{tabular}


TABLE III.-Serum Lipid and Enzyme Levels in 15 Patients with Ischaemic Heart Disease Before and During Clofibrate Treatment

\begin{tabular}{|c|c|c|c|c|c|c|c|c|c|c|c|}
\hline & & & & & & & $\begin{array}{l}\text { Serum } \\
\text { Cholesterol } \\
\text { (mg./100 ml.) }\end{array}$ & 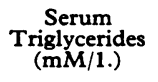 & $\begin{array}{c}\text { Serum Creatine } \\
\text { Kinase } \\
\text { (i.u./1.) }\end{array}$ & $\begin{array}{c}\text { Serum Alkaline } \\
\text { Phosphatase } \\
\text { (K.A. units } / 100 \mathrm{ml} \text {.) }\end{array}$ & $\begin{array}{l}\text { Serum Asparsetate } \\
\text { Aminotransfera } \\
\text { (R.F. units/ml.) }\end{array}$ \\
\hline \multicolumn{7}{|c|}{ Pretreatment: } & $342 \pm 68$ & $2 \cdot 16 \pm 1 \cdot 86$ & $44 \pm 21$ & $7 \cdot 1 \pm 2 \cdot 1$ & $28 \pm 6$ \\
\hline .. & . & .. & .. & . & .. & .. & $336 \pm 67$ & $2 \cdot 25 \pm 2 \cdot 01$ & $48 \pm 26$ & $6 \cdot 7 \pm 2 \cdot 4$ & $24 \pm 5$ \\
\hline \multicolumn{7}{|c|}{ Treatment with clofibrate $1.5 \mathrm{~g} . /$ day: } & $254 \pm 55$ & $1 \cdot 70 \pm 0.79$ & $42 \pm 20$ & $5 \cdot 0 \pm 1 \cdot 7$ & $23 \pm 7$ \\
\hline 12 weeks & .. & . & .. & .. & .. & . & $276 \pm 91$ & $1.50 \pm 0.67$ & $46 \pm 18$ & $5 \cdot 2 \pm 1 \cdot 8$ & $35 \pm 31$ \\
\hline 20 weeks & . & . & .. & .. & .. & . & $272 \pm 62$ & $1.44 \pm 0.85$ & $38 \pm 16$ & $4 \cdot 8 \pm 1 \cdot 6$ & $41 \pm 30$ \\
\hline
\end{tabular}

These findings indicate that mean C.K. activities, are not raised after six months' treatment with clofibrate. Similarly, mean activities of G.O.T. were unchanged; the lower A.P. levels confirm an earlier report (Hellman et al., 1963).

It is of interest that the two men with the highest C.K. values-namely, 320 and 360 i.u./l.-were in the control group and that otherwise these findings might have been attributed to clofibrate therapy. Though we are unable to explain these findings, they accentuate the difficulties which may be encountered in the interpretation of C.K. results in ambulant individuals. These difficulties are partly due to the log-normal pattern of distribution of the results, and partly because average values of C.K. activity from outpatients tend to be about twice as high as those from inpatients (Griffiths, 1966).

There are apparent differences between our findings and those of Langer and Levy (1968), who reported raised C.K. in 5 out of 60 patients receiving clofibrate. Two of their patients

also had muscle symptoms. It seems probable that these differences may be explained by the population studied or the dose of clofibrate used. Three of their five patients had type II hyperlipoproteinaemia and two had type III, while the Edinburgh men, though their lipoprotein types were not assessed, were drawn from a normal population. Of our ischaemic heart disease group there was one patients with type II and three patients with type IV hyperlipoproteinaemia. The different dosage of clofibrate used in the two studies may also explain the discrepancy in results. Langer and Levy (1968) clearly showed in two of their patients that the rise in enzyme was dependent on the dosage of clofibrate used and occurred when doses of 2-4 g. daily were given, whereas in Edinburgh dosages of $1.6 \mathrm{~g}$. daily were used in the normal men and $1.5 \mathrm{~g}$. daily in the patients. We conclude that the absence of significant difference between the mean C.K. levels in the groups studied indicates that this is an uncommon complication of clofibrate treatment, but that our results do not exclude the possibility of rises occurring in a few individual patients.

No instance of myalgia has yet been recorded in the men participating in this trial, and we conclude that the myositic syndrome described by Langer and Levy (1968) is a rare accompaniment of clofibrate therapy.

The raised G.O.T. level seen in two of the patients followed sequentially confirms earlier reports. Though we have no explanation for these observations, it seems unlikely that they were due to a muscular syndrome as they were not accompanied by either a rise in C.K. level or any muscular symptoms.

Reduction in A.P. activity in serum has been reported in a serial analysis of enzyme changes in a smaller group of patients receiving clofibrate (Hellman et al., 1963), though Konttinen and Paloheimo (1963) observed no change in levels of this enzyme. The cause of this change remains obscure; it should be taken into account during the clinical interpretation of alkaline phosphatase results in patients receiving clofibrate therapy.

We are grateful to Professor L. G. Whitby for providing facilities for this work and for his advice. This study was supported by funds from the British Heart Foundation and from Imperial Chemical Industries.

\section{REFERENCES}

Carlson, L. A. (1963). Fournal of Atherosclerosis Research, 3, 334 Griffiths, P. D. (1966). Clinica Chimica Acta, 13, 413

Hellman, L., et al. (1963). fournal of Atherosclerosis Research, 3 454.

Kind, P. R. N., and King, E. J. (1954). fournal of Clinical Pathology, 7, 322.

Konttinen, A., and Paloheimo, J. (1963). fournal of Atherosclerosis Research, 3, 525 .

Lancet, 1968, 2, 1068.

Langer, T., and Levy, R. I. (1968). New England fournal of Medicine, 279, 856.

Morgenstern, S., Kessler, G., Auerbach, J., Flor, R. V., and Klein, B. (1965). Clinical Chemistry, 11, 876.

Oliver, M. F. (1962). Lancet, 1, 1321.

Oliver, M. F. (1968). Bulletin of the New York Academy of Medicine, 44, 1021 .

Reitman, S., and Frankel, S. (1957). American fournal of Clinical Pathology, 28, 56

Rosalki, S. B. (1967). Fournal of Laboratory and Clinical Medicine, 69, 696.

Smith, A. F. (1967), Lancet, 2, 178. 